\title{
ПРОЦЕССУАЛЬНОЕ ПРАВО
}

\author{
PROCEDURAL LAW
}

DOI: $10.22363 / 2313-2337-2019-23-4-586-601$

Научная статья

\section{ПРАВОВЫЕ ОСНОВЫ ГРАЖДАНСКОГО СУДОПРОИЗВОДСТВА СОЦИАЛИСТИЧЕСКОЙ РЕСПУБЛИКИ ВЬЕТНАМ}

\author{
Е.П. Русакова ${ }^{1}$ \\ Российский университет дружбы народов \\ 117198, Москва, Россия, ул. Миклухо-Маклая, д. 6
}

Активное реформирование экономики и правовой системы во Вьетнаме является следствием эффективной политики государства. За последние 30 лет был сделан серьезный экономический скачок, который помог добиться ощутимого результата - снижение бедности населения. Экономическая ситуация демонстрирует постоянный рост. После увеличения на 6,8 процента в 2017 году статистические данные указывают, что рост ВВП ускорился до 7,1 процента в 2018 году. Вьетнам стал первым государством, с которым Евразийский экономический союз (ЕАЭС) заключил Соглашение о свободной торговле (подписано 29 мая 2015 года, вступило в силу 5 октября 2016 года). Эффективным инструментом продвижения инвестиционного взаимодействия служит Российско-Вьетнамская Рабочая группа высокого уровня по приоритетным инвестиционным проектам под председательством министров промышленности и торговли ${ }^{2}$. Постоянный рост экономического сотрудничества двух стран делает необходимым выработки механизмов для разрешения споров (Fedorov, 2018:68; Bel'skaya, 2018:173-179).

Многообразие экономических отношений приводит к возникновению споров, которые требуют выработки эффективных способов их разрешения. Судебный метод защиты права является наиболее универсальным (Mai-Thanh, Tien-Duc, 2017:9-25), и, следовательно, первым был подвергнут преобразованию. Принятие «Стратегии судебной реформы до 2020 года» повлекло ряд существенных изменений.

1 (C) Русакова Е.П., 2019.

\footnotetext{
(c) (i) This work is licensed under a Creative Commons Attribution 4.0 International License https://creativecommons.org/licenses/by/4.0

${ }^{2}$ См.: Межгосударственные отношения России и Вьетнама. Официальный сайт РИА Новости, available at: https://ria.ru/20170629/1497296695.html. (Accessed 25 May 2019).
} 
В настоящей статье автор исследовал основные источники гражданского процесса, проанализировал основные правовые принципы гражданского судопроизводства. Выявлено изменение правовой системы Вьетнама, в которой особую роль занимают разъяснения Верховного Народного суда как источника права.

Ключевые слова: судебная реформа, принципы, источники, судопроизводство, Народный Верховный суд, судебное решение

Финансовая поддержка: Исследование подготовлено при финансовой поддержке РФФИ в рамках научного проекта № 17-03-00093-ОГН-2 «Порядок разрешения финансовых споров в странах АТР» (науч. рук. - Е.Е. Фролова).

\section{ВВЕДЕНИЕ}

В июне 2005 года Политбюро Коммунистической партии Вьетнама 49$\mathrm{NQ} / \mathrm{TW}$ приняло решение, в котором была закреплена «Стратегия судебной реформы до 2020 года» ${ }^{3}$. Это связано с тем, что несмотря на постоянное внимание властей гражданскому законодательству и судебному разбирательству, их качество имело много недостатков. Главными являлись: отсталость от мировых тенденций в судопроизводстве, низкий уровень профессиональной подготовки сотрудников, устаревшая инфраструктура судов (Hoang, 2017:416).

Поэтому принятие стратегии включало выполнение ряда задач:

- совершенствование гражданского законодательства и процедуры;

- проведение четкого различия между административным аппаратом и судами, их юрисдикцией в судебном разбирательстве, путем расширения полномочий и ответственности, а также повышение их независимости и подотчетности в принятии судебных решений;

- совершенствование процедур обжалования и повторного пересмотра решений за счет закрепления перечня оснований;

- разработка и внедрение упрощенных и сокращенных процедур рассмотрения споров;

- создание и развитие организационно-правовой структуры судебных органов;

- совершенствование институтов судебной защиты;

- создание этического, здорового и сильного корпуса судейского и вспомогательного персонала;

- укрепление международного сотрудничества в судебной сфере;

- создание инфраструктуры для обеспечения доступности судебной защиты.

Законодательное закрепление данных задач в 2005 году не привело к быстрым реформистским шагам, это связано с низким уровнем экономического развития страны, ее отставанием от многих других стран (Nguyen, 2015:361-

\footnotetext{
${ }^{3}$ Cм.: MA. Nguyen Hai Ninh. Reform of justice in Vietnam - overview of results and experiences, available at: https://www.aseanlawassociation.org/10GAdocs/Vietnam5-1.pdf. (Accessed 26 May 2019).
} 
363). Кроме того, любые реформы судебной системы и законодательства требуют серьезных финансовых затрат (Ermakova, 2018:192).

Стремление к увеличению экономических связей привело к усложнению общественных отношений, осложненных иностранным элементом. Многообразие международных связей порождает большое число споров, которые необходимо разрешать. Универсальным способом их рассмотрения является судебный. Однако отстающее законодательство не гарантирует сторонам получение эффективной защиты права.

\section{СУДЕБНАЯ СИСТЕМА И ОСНОВНЫЕ ИСТОЧНИКИ ГРАЖДАНСКОГО ПРОЦЕССА}

Правосудие во Вьетнаме осуществляется народными судами, призванными защищать права человека, социалистический строй, интересы государства, законные права и интересы организаций и других лиц.

Судебную систему составляют: Верховный Народный суд; Высшие Народные суды; провинциальные, городские народные суды центрального подчинения; уездные, районные, городские народные суды провинциального подчинения; военные суды.

Верховный Народный суд является высшей судебной инстанцией Социалистической Республики Вьетнам (Bektimirova, Lipilina, Mazyrin, Efimova, 2014:65-87), осуществляет функции надзорной и кассационной инстанций по пересмотру вступивших в законную силу судебных постановлений и решений, а именно Совет Верховного Народного Суда. Высшие Народные Суды осуществляют полномочия апелляционной инстанции на решения и приговоры первой инстанции провинциальных, городских народных судов центрального подчинения, которые не вступили в законную силу и на вступившие в законную силу судебные акты полномочия кассационной инстанции. Высшие Народные суды состоят из комитета судей, суда по уголовным делам, суда по гражданским делам, суда по семейным делам и по делам несовершеннолетних, а также вспомогательного органа.

Статья 30 Закона об организации народных судов № 62/2014/QH13 ${ }^{4}$ закрепляет возможность создания новых судов, так, по предложению Председателя Верховного Народного суда Постоянный комитет Национального Собрания может принять решение об учреждении любого специализированного суда.

Основным источником гражданского судопроизводства являются законы. Первостепенной является Конституция Социалистической Республики Вьетнам 1992 (в ред. 2013 г.) (далее - СРВ), ряд статей которой закрепляют основные принципы правового государства: статья 16 закрепляет равенство

\footnotetext{
${ }^{4}$ Luật Tổ Chức Tòa Án Nhân Dân. Закон об организации Народных Судов, available at: https://thuvienphapluat.vn/van-ban/Bo-may-hanh-chinh/Luat-to-chuc-Toa-an-nhan-dan-2014-259724.aspx (Accessed 28 May 2019).
} 
всех перед законом, статья 30 гарантирует каждому право на защиту и получение материальной компенсации, а также восстановление чести и достоинства, статья 31 содержит презумпцию невиновности лица, до тех пор пока не вступит в законную силу приговор суда. Так, лицо, обвиняемое в совершении уголовного преступления, считается невиновным до тех пор, пока его вина не будет доказана в установленном законом порядке и приговор суда не вступит в законную силу, в этой же статье закреплен основной принцип осуществления правосудия независимым и беспристрастным судом, глава 8 посвящена судебной системе и прокуратуре, которая называется «Народные Суды, Народные Прокуратуры».

В Конституции закреплены и получили развитие в отраслевом законодательстве следующие принципы правосудия: законность (ст. 8); осуществление правосудия только судом (ст. 104); коллегиальность рассмотрения дел во всех судах (ст. 104); рассмотрение в суде первой и второй инстанций дел с участием народных заседателей (ст. 103); независимость судей и народных заседателей и подчинение их только закону (ст. 103 и 104); открытое разбирательство дел во всех инстанциях; гласность судопроизводства (ст. 103).

Следующим важным источником является Гражданский процессуальный кодекс 2015 года № 92/2015/QH13, который вступил в силу с 1 июля 2016 года (в котором 63 статьи были сохранены от предыдущего кодекса, изменены и дополнены 350 статей, добавлены 104 статьи, отменены 7 статей) ${ }^{5}$.

Целями принятия кодекса является установление справедливости, защита прав человека, социалистического строя, интересов государства, законных прав и интересов государственных органов, организаций, частных лиц; а также воспитательная ${ }^{6}$.

Гражданский процессуальный кодекс Вьетнама (далее - ГПК) состоит из 10 частей, 42 глав и 517 статей: Первая часть: Общие положения; Вторая часть: Порядок разрешения дел в суде первой инстанции; Третья часть: Порядок разрешения дел в апелляционных судах; Часть четвертая: Разрешение гражданских дел в ускоренном производстве; Часть пятая: Процедуры пересмотра судебных решений и постановлений, вступивших в законную силу; Часть шестая: Виды производств; Часть седьмая: Порядок признания и исполнения иностранных судебных и арбитражных решений; Часть восьмая: Порядок разрешения гражданских дел с участием иностранных лиц; Часть девятая: Исполнение гражданских судебных и арбитражных решений; Часть десятая: Порядок рассмотрения различных актов, препятствующих гражданскому судопроизводству, жалоб и обвинений.

\footnotetext{
${ }_{5}^{5}$ Новые пункты Гражданско-процессуального кодекса 2015 года, available at: https://thukyluat.vn/ news/phan-tich-chinh-sach/nhung-diem-moi-cua-bo-luat-to-tung-dan-su-2015-19274.html (Accessed 17 May 2019).

${ }^{6}$ The Civil Procedure Code of the Socialist Republic of Vietnam, available at: https://www.wipo.int/edocs/ lexdocs/laws/en/vn/vn083en.pdf (Accessed 26 May 2019).
} 
Помимо установления новых принципов гражданского процесса (Bui Thi, Lien, 2013:256-593) гражданский процессуальный кодекс впервые закрепил иную форму подачи искового заявления посредством информационно-телекоммуникационной сети «Интернет» на официальном сайте суда. Однако пока говорить о повсеместном использовании данной формы рано из-за отсутствия технологического оснащения. С 2017 года только Верховный Народный суд начал публиковать некоторые судебные решения в Интернете.

Впервые 8 Глава ГПК Вьетнама посвящена упрощенному производству, которое может применяться при рассмотрении дела в первой инстанции и апелляционном производстве 7 . В статье 317 ГПК закреплены условия, при которых дело может быть рассмотрено в упрощенном порядке: а) стороны признали свои обязательства, спор носит несложный характер, достаточно доказательств для вынесения решения; б) известен адрес и местонахождение сторон; в) если ни одна из сторон не проживает за границей, и спорное имущество не находится за рубежом, за исключением если между сторонами достигнуто соглашение о рассмотрении спора в порядке упрощенного производства или стороны представили правоустанавливающие документы на имущество и соглашение, разрешающее спор.

Кроме того, в соответствии со статьей 194 ГПК Вьетнама был увеличен срок на подачу жалобы на возврат искового заявления с трех дней до десяти дней. Долгое время это являлось проблемой для реализации своего права на судебную защиту путем подачи процессуальных документов в суд.

Источниками гражданского процессуального права являются и иные кодифицированные акты, регулирующие преимущественно материальноправовые отношения (Eliseev, 2000:29). Например, ряд процессуальных норм содержится в Гражданском кодексе, Жилищном кодексе, Трудовом кодексе и других законах.

Так, Гражданский кодекс 2010 года предусматривает последствия несоблюдения формы сделок, институт эмансипации, вопросы правоспособности и дееспособности; Земельный кодекс 2014 года содержит нормы, применяемые судом при рассмотрении и разрешении земельных споров; Закон о браке и семье 2015 года регулирует вопросы установления отцовства, признания брака недействительным, лишения родительских прав; Трудовой кодекс 2012 года закрепляет порядок рассмотрения трудовых споров, например, в соответствии со статьей 51 инспекция труда лишилась права признавать трудовой договор недействительным, теперь только народные суды имеют право признавать недействительными трудовые договоры.

\footnotetext{
${ }^{7}$ Новые пункты Гражданско-процессуального кодекса 2015 года, available at: https:/thukyluat.vn/ news/phan-tich-chinh-sach/nhung-diem-moi-cua-bo-luat-to-tung-dan-su-2015-19274.html (Accessed 28 May 2019).
} 
Процессуальные нормы могут содержаться и в других законах. Это, например, Закон об организации народных прокуратур 63/2014/QH13, принят 24/11/2014, регулирует вопросы, связанные с участием прокурора в гражданском судопроизводстве.

К источникам гражданского процессуального права относятся международные правовые акты Вьетнама (например, Конвенция по вопросам гражданского процесса 1954 г., а также Протокол к договору между Российской Федерацией и Социалистической Республикой Вьетнам о правовой помощи и правовых отношениях по гражданским и уголовным делам от 25 августа 1998 г.).

Конституция Вьетнама закрепляет, что общепризнанные принципы и нормы международных договоров входят в правовую систему Вьетнама. Статья 2 ГПК Вьетнама конкретизирует это положение: «Если международным договором Вьетнама установлены иные правила гражданского судопроизводства, чем те, которые предусмотрены законом, применяются правила международного договора».

Сфера применения гражданского процессуального законодательства Вьетнама ограничивается территорией, на которую распространяется суверенитет Вьетнама. Гражданские процессуальные нормы имеют обязательную силу для всех лиц, находящихся на территории Вьетнама. На отношения с участием иностранных граждан, лиц без гражданства, иностранных или международных организаций гражданское процессуальное законодательство распространяется в соответствии с правилами, установленными раздел 8 гл. 39 ГПК Вьетнама.

Необходимо отметить Закон 80/2015/QН13 об обнародовании нормативных актов 2015 года, который в статье 4 закрепил, что принятые Верховным Народным судом разъяснения являются источником права наряду с законами, декретами, постановлениями и другими актами, что совсем не свойственно для стран, где основным источником права является закон.

\section{ПРИНЦИПЫ ГРАЖДАНСКОГО ПРОЦЕССА}

Основные принципы гражданского судопроизводства закреплены в разделе 2 главы 1 ГПК, которая так и называется «Основные принципы». Согласно законодательству под принципами понимаются основополагающие идеи, положения, руководящие начала по вопросам осуществления судопроизводства по гражданским делам, закрепленные и раскрытые в нормах гражданского процессуального права. Всего содержится 23 основных принципа, некоторые из которых появились исключительно в данном кодексе.

Основным принципом является обязанность соблюдения социалистического законодательства в гражданском судопроизводстве, который означает, что деятельность судебных органов, председательствующих лиц, участников гражданского процесса и других лиц, а также учреждений и организаций в гражданском процессе должна соответствовать положениям ГПК. 
Иными словами, речь идет о соблюдении принципа законности, согласно которому весь гражданский процесс урегулирован нормами Гражданского процессуального кодекса и другими законами.

Долгое время в социалистическом Вьетнаме было неправильным подвергать сомнению действия государственных или иных органов, а следовательно, обращаться в суд за защитой, например, по делам из публичных правоотношений, поэтому теперь эта возможность закреплена законодательно, право обращаться в суд за защитой законных прав и интересов. Данный принцип гарантирует всем лицам право на судебную защиту (возможность подавать исковые заявления и требовать их рассмотрения путем вынесения судебного решения). Но главное в этом принципе - вторая часть, согласно которой суды не должны отказывать в рассмотрении гражданского дела по той причине, что нет конкретной нормы, регулирующей данные общественные отношения.

Суд должен исходить из того, что если нет конкретной нормы, но гражданский спор существует, то он подпадает под действие норм Гражданского кодекса Вьетнама и, следовательно, должен быть разрешен в соответствии с Гражданским кодексом и Гражданским процессуальным кодексом.

Появление данного принципа делает судебное разбирательство более эффективным, так как судья не сможет отнестись к спору формально, а должен будет исследовать все обстоятельства дела, уточнить правовые позиции сторон и вынести судебное решение на основании норм закона.

Право сторон на совершение процессуальных действий и самоопределение в процессе является принципом, в соответствии с которым заинтересованные стороны вправе решать, подавать ли гражданские иски, заявления в суды, а те в свою очередь принимают иски от этих лиц и разрешают их согласно заявленным требованиям. При рассмотрении гражданского дела стороны вправе изменить исковые требования, отказаться от иска и заключить мировое соглашение, если оно не противоречит законодательству и социалистической этике. Если проводить сравнение с принципами российского гражданского процесса, то речь идет о принципе диспозитивности.

Одним из важных принципов является право представлять доказательства и участвовать в доказывании в гражданском процессе. Так, всем лицам, участвующим в деле и выступающим в защиту своих прав и интересов или других лиц, предоставляется право и вменяется обязанность представлять доказательства, заявлять ходатайства в суде, обосновывая свои требования и их законность, а суд в свою очередь должен содействовать в их сборе, истребовании и проверке. Новым в этом принципе является установление обязанности предоставлять доказательства.

Долгое время существовала проблема в своевременном получении необходимой информации в гражданском судопроизводстве, чем зачастую затягивались сроки, поэтому появился принцип ответственности компетентных лиц, учреждений и организаций за предоставление материалов и доказательств в процессе, который означает, что все учреждения, организации и частные лица 
в пределах своей компетенции обязаны предоставить все материалы и доказательства участвующим в деле лицам, суду, народной прокуратуре, находящихся в их распоряжении или под их управлением, в достаточном объеме и своевременно, по ходатайству заинтересованных лиц, и нести юридическую ответственность за вручение этих материалов и доказательств; а в случае, если они не могут это сделать, обязаны направить письменное уведомление, содержащее объяснение, в адрес этих лиц.

Кроме того, закреплен принцип участия государственных органов, организаций и частных лиц в гражданском процессе, согласно которому государственные органы, организации и частные лица имеют право и обязаны участвовать в гражданском процессе, способствуя законному и оперативному разрешению дел в судах.

В процессуальном законодательстве закреплен конституционный принцип равенства прав и обязанностей участников в гражданском судопроизводстве, который гарантирует, что все люди равны перед законом независимо от их этнической принадлежности, вероисповедания, образования, профессии и социального уровня. Аналогичный подход установлен в отношении всех лиц, участвующих в процессе, причем ответственность за создание равных условий несет суд.

Одним из социально значимых принципов является обеспечение лицам, участвующим в деле, их права на защиту лично или через представителя, согласно данному принципу все заинтересованные лица имеют право защищать свои законные права и интересы лично или посредством участия адвокатов, а также других лиц, которые удовлетворяют требованиям, закрепленным в законе, а ответственность за реализацию этого права возложена на суды. Государство обязано предоставить помощника по правовым вопросам некоторым категориям лиц, указанных в законе, для осуществления ими права на судебную защиту своих законных прав и интересов.

В социалистическом Вьетнаме, как и в других странах мира, законодательно закрепляется внедрение процедуры медиации в гражданский процесс, поэтому появился принцип осуществления медиации в гражданском судопроизводстве, согласно которому суды несут ответственность за применение процедуры медиации и создание благоприятных условий для сторон в достижении соглашения по разрешению гражданского дела.

Это один из новых принципов, появившихся в процессуальном законодательстве Вьетнама, отражает современные тенденции его реформирования. Главным является закрепление ответственности судьи за проведение медиации, так как только таким образом может быть достигнута эффективность данной процедуры, поскольку суды зачастую пренебрегают обязанностью предложить сторонам воспользоваться ею. Для социалистического Вьетнама эта процедура может быть более востребованной (Nguyen, Teramachi, 2012:3245), чем судебное разбирательство, так как это серьезно удешевит процедуру разрешения спора. 
Сохранился в новом законодательстве принцип участия народных заседателей в гражданском деле, в соответствии с которым, при рассмотрении дел по первой инстанции в процессе участвуют народные заседатели, за исключением упрощенного производства, причем в ходе вынесения решения компетенция народных заседателей одинакова с судьями.

Участие в рассмотрении дел непрофессиональных судей, так называемый народный элемент, обеспечивает более всесторонний подход к делу, а нетолько профессиональный. Следовательно, можно констатировать наличие принципа коллегиальности рассмотрения дела. Суд рассматривает гражданские дела коллегиально и принимает решения большинством голосов, за исключением упрощенного производства.

В гражданском процессуальном кодексе закреплены два взаимосвязанных принципа: независимости и ответственности судей, народных заседателей и должностных лиц, вовлеченных в процесс. Принцип независимости судей и народных заседателей означает, что при рассмотрении гражданских дел судьи и народные заседатели независимы и руководствуются только законами. Любые действия, препятствующие деятельности судей и народных заседателей, строго запрещены законом. Принцип ответственности судебных органов и должностных лиц в гражданском процессе означает, что судьи и сотрудники судов должны уважать и подчиняться людям. Судьи несут ответственность за защиту справедливости, прав человека, гражданских прав, социалистического режима, интересов государства, законных прав и интересов организаций и отдельных лиц (Frolova, Inshakova, Dolinskaya, 2019:101-108). Прокуратура должна способствовать обеспечению строгого и последовательного соблюдения закона. Судебные органы и должностные лица должны хранить государственную тайну и другие виды тайн, ставшие им известными входе процесса, сохранять национальные обычаи, защищать права и интересы несовершеннолетних лиц. Должностные лица несут юридическую ответственность за выполнение своих задач и полномочий, а в случае нарушения закона, в зависимости от характера и серьезности, будут подвергнуты дисциплинарному взысканию, вплоть до уголовной ответственности. Кроме того, если будет доказано, что в результате таких действий был причинен ущерб, то потерпевшая сторона получит компенсацию от государственного органа.

В отличие от других форм защиты права для судебной характерен принцип быстрого и открытого судебного разбирательства, который означает, что гражданский процесс должен проводиться своевременно и в сроки, установленные законом, а также по общему правилу должен быть публичным, за исключением случаев, предусмотренных законом.

Отдельным принципом выделено обеспечение беспристрастности и объективности в гражданском процессе, согласно которому председатель суда, судьи, народные заседатели, омбудсмены, судебные секретари, прокуроры, инспекторы, переводчики, эксперты-свидетели и другие лица должны выполнять свои задачи и осуществлять свои полномочия беспристрастно, а назначение су- 
дей должно обеспечить условия для беспристрастного и объективного выполнения своих задач и полномочий.

Касаемо процедуры пересмотра судебных решений, во Вьетнаме, как и в других азиатский странах, характерно соблюдение двухуровневого судебного разбирательства, которое предполагает наличие возможности обжаловать решения и определения первой инстанции в апелляционном порядке, в течение срока, установленного в законе, по истечении которого данные судебные акты вступают в законную силу. Если срок на апелляционное обжалование истек, но есть основания предполагать, что существуют нарушения закона или новые обстоятельства, то решения и определения могут быть обжалованы в кассационном порядке или по вновь открывшимся обстоятельствам.

Это новый процессуальный принцип, который закрепляет право на обжалование судебного акта, причем апелляция рассматривается как обязательная стадия процесса, а если срок пропущен, то у сторон есть возможность подать кассационную жалобу. Кроме того, если в деле появятся новые обстоятельства, то решение можно пересмотреть по новым обстоятельствам. В Гражданском процессуальном кодексе определены все кассационные инстанции в гражданском судопроизводстве. Так, Верховный Народный суд является кассационной инстанцией на решения и постановления всех судов; Провинциальные народные суды - на решения народных районных судов.

Кроме того, участникам гарантируется право на подачу жалоб и претензий в гражданском процессе, так органы, организации и отдельные лица имеют право подавать жалобы на действия/бездействие должностных лиц судебных и иных органов, учреждений, организаций, отдельных лиц, участвующих в гражданском процессе. Компетентные органы, организации или частные лица должны принять и рассмотреть жалобы и претензии, письменно уведомив заявителей о результатах.

Участникам гражданского процесса гарантируется обеспечение исполнения судебных решений и определений, согласно данному принципу все вступившие в законную силу судебные акты должны строго соблюдаться всеми учреждениями, организациями и частными лицами, а лица, в чью компетенцию входит обеспечение их, несут ответственность за реализацию этой задачи. Суды могут обращаться в компетентные органы с ходатайством об уведомлении их о ходе и результатах производства, а те в свою очередь обязаны ответить на этот запрос.

Производство в гражданском процессе как устно, так и письменно осуществляется на вьетнамском языке. Лицам, являющимся представителями других этнических групп предоставляется переводчик.

Надзор за соблюдением законности в гражданском процессе осуществляет прокуратура, которая вправе участвовать на всех стадиях процесса: от подачи заявления в суд первой инстанции до жалобы в вышестоящие судебные инстанции, в целях обеспечения законного и своевременного разрешения гражданских дел. Прокуратура участвует в процессе по делам, касающихся государ- 
ственной собственности, интересов государства, землепользования, жилища, а также когда стороной в деле являются несовершеннолетние, недееспособные или с ограниченными возможностями лица.

В Гражданском процессуальном кодексе закреплена ответственность судов за направление судебных актов участникам процесса, согласно данному принципу суды обязаны надлежащим образом уведомлять стороны и других лиц, участвующих в деле, о вынесенных решениях. Кроме того, этот процесс осуществляется под контролем самого суда.

Особенностью процессуальных принципов является соотношение принципов устности и непосредственности в один, так суды должны обеспечить лицам, участвующим в деле, реализацию права на участие в устных прениях в судах первой, апелляционной, кассационной инстанциях, а также по вновь открывшимся обстоятельствам. В ходе вынесения решения каждое доказательство должно быть исследовано всесторонне и публично, за исключением случаев, предусмотренных законом. Суд руководит устными прениями, задает вопросы и выносит решение на основе результатов прений.

Данный принцип гарантирует сторонам, что судебное разбирательство будет длиться до тех пор, пока не будет вынесено судебное решение и оно не вступит в законную силу. Кроме того, процесс установления обстоятельств по делу и позиций сторон зависит от суда, ему отводится активная роль в процессе доказывания. Многие юристы и ученые считают, что это прорыв в судебной деятельности, одно из важных положений и дополнений Гражданского процессуального кодекса 2015 года.

\section{ПРОБЛЕМЫ РЕФОРМИРОВАНИЯ ГРАЖДАНСКОГО ПРОЦЕССА}

Процесс реформирования гражданского судопроизводства во Вьетнаме проходит крайне медленно. Низкий уровень жизни граждан Вьетнама, борьба с бедностью делает невозможной реализацию тех задач, которые поставило государство. Проблемы в правосознании общества делают невозможным реализацию права на судебную защиту (Frolova, 2016:36-40). Отсутствие профессиональных кадров также влияет на темпы достижения поставленных задач.

Помимо законодательных изменений судебная реформа предусматривает создание условий для осуществления судьями своих полномочий: предоставление экономических, социальных и правовых гарантий, технического оснащения судов.

Одной из важных проблем социалистического Вьетнама является отсутствие профессиональных кадров, это касается судейского корпуса. Низкий уровень подготовки делает невозможным исполнение прогрессивных задач поставленных перед судами (Burukina, Dudin, Lyasnikov, Frolova, 2019:10030-10039).

Правовые пробелы в законодательстве долгое время лишали стороны возможности получить судебное решение, из-за отсутствия норм закона, которые бы регулировали данные правоотношения. Одним из наиболее важных яв- 
ляется принцип соблюдения законодательства социалистического Вьетнама, согласно которому суды не должны отказывать в рассмотрении гражданского дела по той причине, что нет конкретной нормы, регулирующей данные общественные отношения. Следовательно, одним из способов восполнения пробелов в законодательстве является аналогия права.

Большую роль в данном процессе приобрели разъяснения Верховного Народного суда, согласно которым те общественные отношения, которые не урегулированы нормами закона, получают регулирование за счет вынесения судебных разъяснений, которые приобретают огромное значение как для законотворчества, так и правоприменения (Brian, J.M. Quinn, 2002). Нужно констатировать, что такой подход не лишен недостатков, так как не гарантирует отсутствие противоречий в регулировании общественных отношений в будущем. Однако можно утверждать, что правовая система социалистического Вьетнама постепенно становится прецедентной.

Внедрение новых процедур рассмотрения споров делает судебное разбирательство более привлекательным: применение процедуры посредничества и упрощенное производство. Но их законодательное закрепление является недостаточным для того, чтобы эти процедуры стали эффективными. Касаемо процедуры посредничества непонятен механизм осуществления данной процедуры, а упрощенное производство возможно только по отдельным категориям дел.

Касаемо внедрения цифровых технологий в гражданский процесс можно с уверенностью говорить, что Вьетнам отстает от большинства стран мира.

Однако появление новых правовых принципов гарантирует, что законодательство Вьетнама постепенно начинает соответствовать мировым трендам гражданского судопроизводства.

\section{ЗАКЛЮЧЕНИЕ}

Происходящие глобальные изменения общественных отношений привели к необходимости изменения правовых систем во многих странах АзиатскоТихоокеанского региона (Artemieva, Ermakova, Ivanovskaya, Protopopova, Rusakova, Sitkareva, Frolova, 2019:416). Закон 80/2015/QH13 Вьетнама об обнародовании нормативных актов 2015 года в статье 4 закрепил, что принятые Верховным народным судом разъяснения являются источником права наряду с законами, декретами, постановлениями и другими актами. Очевидна невозможность соответствия нормативных актов существующим общественным отношениям (Hridina, 2017:140).

Одним из важнейших направлений государственной политики стало реформирование судопроизводства и законодательства. Во многие нормативные акты были внесены изменения, а также был принят новый Гражданский процессуальный кодекс 2015 года, который закрепил новые прогрессивные принципы, 
способы разрешения споров, изменил подходы к судебному разбирательству, которые долгое время не были характерны для социалистического Вьетнама.

Правовая система Вьетнама сочетает в себе: сохранение социалистических идеалов и внедрение новых современных принципов. Данный процесс проходит очень медленно, несмотря на предпринятые прогрессивные шаги. Социалистический Вьетнам отстает от многих азиатских стран из-за сложной экономической ситуации, долгого нахождения в изоляции. Низкая инвестиционная привлекательность, отсутствие современных правовых институтов, увеличение роли судебной власти тормозит реформирование государства.

Во Вьетнаме 14 января 2019 года вступило в силу преференциальное торговое соглашение в рамках Транстихоокеанского партнерства между 12 странами Азиатско-Тихоокеанского региона, целью которого является снижение тарифных барьеров, а также регулирование внутренних правил в странахучастницах в таких областях, как трудовое право, экология, интеллектуальная собственность и другие, на которое возлагаются большие надежды, поэтому возможны в скором времени серьезные изменения различных сфер, а также такого важного социального института, как суд (Rusakova, 2018:69).

\section{БИБЛИОГРАФИЧЕСКИЙ СПИСОК / REFERENCES}

Artemieva, Yu.A., Ermakova, E.P., Ivanovskaya, N.V., Protopopova, O.V., Rusakova, E.P., Sitkareva, E.V, Frolova, E.E. (2019) Resolution of financial disputes in Asia-pacific countries (Australia, Hong Kong, India, Indonesia, China, Malaysia, New Zealand, Singapore, USA, Thailand, Japan). Frolova E.E., Ermakova E.P. (eds.). Moscow: Infotropic Media Publ. (in Russian).

Артемьева Ю.А., Ермакова Е.П., Ивановская Н.В., Протопопова О.В., Русакова Е.П., Ситкарева Е.В., Фролова Е.Е. Разрешение финансовых споров в странах АТР (Австралия, Гонконг, Индия, Индонезия, Китай, Малайзия, Новая Зеландия, Сингапур, США, Таиланд, Япония). Под редакцией проф. Е.Е. Фроловой, проф. Е.П. Ермаковой // Москва: Инфотропик Медиа, 2019. 416 с.

Bektimirova, N. N., Lipilina, I. N., Mazyrin, V. M., Efimova, L. M. (2014) Politicheskie sistemy stran Yugo-Vostochnoi Azii (uchebnoe posobie) 2-oe izdanie, pererab. i dopolnennoe N. N. Bektimirova, I. N. Lipilina, V. M. Mazyrin, L. M. Efimova [Political systems of the countries of Southeast Asia (study guide) $2^{\text {nd }}$ edition, revised. and supplemented. N.N. Bektimirova, I.N. Lipilina, V.M. Mazyrin, L.M. Efimova]. Moscow: Lenand Publ. (in Russian).

Бектимирова Н. Н., Липилина И. Н., Мазырин В. М., Ефимова Л. М. Политические системы стран Юго-Восточной Азии (учебное пособие) 2-ое издание, перераб. и дополненное / Н. Н. Бектимирова, И. Н. Липилина, В. М. Мазырин, Л. М. Ефимова. М.: Ленанд, 2014. 256 с.

Bel'skaya, Ye.I. (2018) Features of the dispute resolution mechanism under the free trade agreement between the EEU and Vietnam. In the collection: Actual issues of the development of Russian statehood and public rights of the IV All-Russian Scientific and Practical Conference. Trofimov, Ye.V. (ed.). 173-177. (in Russian).

Бельская Е.И. Особенности механизма разрешения споров, предусмотренного соглашением о свободной торговле между ЕАЭС и Вьетнамом. В сборни- 
ке: Актуальные вопросы развития российской государственности и публичного праваматериалы IV всероссийской научно-практической конференции. Ответственный редактор Е.В. Трофимов. 2018. С. 173-177.

Burukina, O.A., Dudin, M.N., Lyasnikov, N.V., Frolova, E.E. (2019) Interrelation Between the University's Social Responsibility and Sustainability. $11^{\text {th }}$ International conference on education and new learning technologies, Palma, Spain. Edulearn Proceedings: IATED Publ. 10030-10039. DOI: 10.21125/edulearn.2019.2509.

Brian, J.M. Quinn (2002) Legal Reform and its Context in Vietnam. Columbia Journal of Asian Law, 15(2), available at: https://journals.library.columbia.edu/index.php/cjal/article/view/3211 (Accessed 26 May 2019).

Bui Thi Bich, Lien (2013) Arbitration in Vietnam, International Commercial Arbitration in Asia, Chapter 15, 569-593.

Dudin, M.N., Shakhov, O.F., Shakhova, M.S., Rusakova, E.P., Sizova, Yu.S. (2019) Digital Technologies as a Driver of Intellectual Stratification of Human Resources: Socio-Economic Inequality. International Journal of Recent Technology and Engineering. 8 (2). 44364440. DOI: 10.35940/ijrte.B3333.078219

Eliseev, N.G. (2000) Civil procedural law of foreign countries: sources, judicial system, jurisdiction: textbook. Allowance. Tutorial. N.G. Eliseev; MGIMO (University) of the Ministry of Foreign Affairs of the Russian Federation; Issled. private law center. Moscow: Statut Publ. (in Russian).

Елисеев Н.Г. Гражданское процессуальное право зарубежных стран: источники, судоустройство, подсудность: учеб. пособие / Н. Г. Елисеев ; МГИМО(У) МИД РФ ; Исслед. центр частного права. М.: Статут, 2000. 270 с.

Ermakova, E.P. (2018) Reforms of civil justice, arbitration and mediation in foreign countries 2014-2018 (Australia, England, Germany, Canada, USA, France). Infotropic Media Publ. (in Russian).

Ермакова Е.П. Реформы гражданского судопроизводства, арбитража и медиации в зарубежных странах 2014-2018 гг. (Австралия, Англия, Германия, Канада, США, Франция). Инфотропик Медиа, 2018. 192 с.

Fedorov, N.V. (2018) New Policy towards Vietnam? State Administration of the Russian Federation and a Realization of the Free Trade Agreement between the EAEU and Vietnam. Public Administration Issues, Special Issue (electronic edition), No 5, 68-79. DOI: 10.17323/1999-5431-2018-0-5-68-79. (in Russian).

Федоров Н.В. Новая политика в отношении Вьетнама? Государственная администрация Российской Федерации и реализация Соглашения о свободной торговле между ЕАЭС и Вьетнамом. Вопросы государственного и муниципального управления, специальный выпуск (электронное издание), 2018. № 5. С. 68-79. DOI: 10.17323/1999-5431-2018-0-5-68-79.

Frolova, E.E. (2016) To a question of leg al regulation of formation of Civil Society. RUDN Journal of Law. (1), 36-40.

Фролова E.E. К вопросу правового обеспечения формирования гражданского общества. Вестник Российского университета дружбы народов. Серия: Юридические науки. 2016. №1. С. 36-40.

Frolova, E.E., Inshakova, A.O., Dolinskaya, V.V. (2019) The Concept and Legal Framework for Judging Corporate Conflicts on the us Financial Market. "Conflict-Free" Socio-Economic Systems: Perspectives and Contradictions Bingley, West Yorkshire Bingley, West Yorkshire, Emerald Group Publishing Limited Publ. 101-108. DOI: 10.1108/978-1-78769993-920191012. 
Hoang, Chi Bao (2017) New theoretical approaches in documents of the XII Congress of the Communist party of Vietnam, Vietnam Studies. Vol. 7. Moscow: IFES RAS Publ. (in Russian).

Хоанг Ти Бао. Новые теоретические подходы в документах XII съезда Компартии Вьетнама // Вьетнамские исследования. Вып. 7. Опыт обновления во Вьетнаме: современность и история. М.: ИДВ РАН, 2017. 416 с.

Hridina, N.A. (2017) Zakonodatelistvo stran Aziatsko-Tihookeanskogo regiona: uchebnoe posobie [The legislation of the countries of the Asia-Pacific region: a textbook]. N.A. Hridina, E.N. Valeev, A.V. Ilinykh. Khabarovsk: Pacific Publishing House state university Publ. (in Russian).

Хридина Н.А. Законодательство стран Азиатско-Тихоокеанского региона: учебное пособие // Н.А. Хридина, Э.Н. Валеев, А.В. Ильиных. Хабаровск: Изд-во Тихоокеан. гос. ун-та, 2017. 140 с.

Mai-Thanh, Le., Tien-Duc, N. (2017) Vietnam's Choices of Peaceful Settlement Means in the Wake of the South China Sea Arbitration ruling. Russia and the Pacific. No 2, 9-25.

Nguyen Thi Minh Huong, Teramachi Nobio, (2012) Vietnam-Japan trade structure in 1991-2010, Vietnam's socio-economic development. No 72. 32-45.

Nguyen, T.K.A. (2015) General Provisions of Civil Procedure Rights in Vietnam. V sbornike: Sravnitel'noe pravo i problemy chastno-pravovogo regulirovaniya v Rossii i zarubezhnykh stranakh. Sbornik statei Mezhdunarodnoi nauchno-prakticheskoi konferentsii pamyati doktora yuridicheskikh nauk, professora V.K. Puchinskogo [In the collection: Comparative law and the problems of private regulation in Russia and foreign countries. Scientific and practical conferences in memory of Doctor of Law, Professor V.K. Puchinsky]. 361-363. (in Russian).

Нгуен T.К.А. Общие положения гражданского процессуального права во Вьетнаме. В сборнике: Сравнительное право и проблемы частноправового регулирования в России и зарубежных странах. Сборник статей Международной научнопрактической конференции памяти доктора юридических наук, профессора В.К. Пучинского. 2015. С. 361-363.

Rusakova, E.P. (2018) Private litigation in BRICS countries. Moscow: RUDN University Publ. Русакова Е.П. Рассмотрение частноправовых споров в странах БРИКС. М.: Российский университет дружбы народов, 2018. 302 с.

\section{Об авторе:}

Русакова Екатерина Петровна - кандидат юридических наук, доцент, доцент кафедры гражданского права и процесса и международного частного права, юридический институт, Российский университет дружбы народов

ORCID ID: 0000-0001-6488-0754

e-mail: rusakova-ep@rudn.ru

\section{Для цитирования:}

Русакова Е.П. Правовые основы гражданского судопроизводства Социалистической Республики Вьетнам // Вестник Российского университета дружбы народов. Серия: Юридические науки. 2019. Т. 23 № 4. С. 586-601. DOI: 10.22363/2313-2337-2019-23-4-586-601.

Дата поступления в редакцию: 10 июня 2019 г.

Дата принятия к печати: 15 октября 2019 г. 


\title{
THE LEGAL FRAMEWORK OF CIVIL PROCEEDINGS OF THE SOCIALIST REPUBLIC OF VIETNAM
}

\author{
Ekaterina P. Rusakova \\ Peoples' Friendship University of Russia \\ 6, Miklukho-Maklaya str., 117198, Moscow, Russia
}

The economic and legal active reform is the result of the active policy of the state in Vietnam. Over the past 30 years, a major economic leap which has helped to achieve a tangible result meanly the reduction of poverty has been made. The economic situation demonstrates constant growth. The extreme poverty rate has been reduced to below 3 per cent. After rising 6.8 percent in 2017, statistics indicate that GDP growth accelerated to 7.1 percent in 2018. Vietnam was the first state that signed a free trade Agreement (signed on May 29, 2015, entered into force on October 5, 2016) with Eurasian Economic Union (EAEU). The Russian-Vietnamese high-level working group on priority investment projects, chaired by the Ministers of industry and trade, is an effective tool for promoting investment cooperation. The constant growth of economic cooperation between two countries makes necessary to develop mechanisms for disputes resolution.

New economic relations need their legal consolidation and regulation. The diversity of economic relations leads to disputes, which require the development of an effective mechanism for their resolution. Judicial remedy is the most popular, therefore the same needs to be reformed. The adoption of the "Strategy of judicial reform until 2020" led to a number of changes, such as amendments to the basic law of the country, the adoption of new laws, changes in the legal system.

In the present article the author investigated the main sources of civil procedure, analyzed the basic legal principles of civil proceedings. The article reveals the change in the legal system of Vietnam, in which the explanations of the Peoples' Supreme court as a source of law that plays a special role.

Key words: judicial reform, principles, sources, legal proceedings, peoples' Supreme court, judicial decision

Funding information. The study was prepared with the financial support of the Russian Foundation for Basic Research in the framework of the research project No. 17-03-00093-OGN-2 "Procedure for resolving of financial disputes in the APR countries" (supervisor - E.E. Frolova).

\section{About author:}

Ekaterina P. Rusakova - Candidate of Legal Science, Associate Professor, Associate Professor of the Department of Civil Law and Procedural Law and Private International Law, Law Institute, Peoples' Friendship University of Russia

ORCID ID: 0000-0001-6488-0754

e-mail: rusakova-ep@rudn.ru

\section{For citation:}

Rusakova, E.P. (2019) The legal framework of civil proceedings of the Socialist Republic of Vietnam. RUDN Journal of Law. 23 (4), pp. 586-601. DOI: 10.22363/2313-2337-2019-23-4586-601.

Article received June 10, 2019

Article accepted October 15, 2019 